\title{
CAUSATIVE CONSTRUCTION IN ASAHAN MALAY LANGUAGE: MORPHOLOGICAL CAUSATIVE ANALYSIS
}

\author{
${ }^{1}$ Muhammad Yusuf $(2)$ Mulyadi \\ 1,2Universitas Sumatera Utara \\ Corresponding email: yusuf_my@usu.ac.id
}

\begin{abstract}
This study attempts to describe morphological causative in Asahan Malay Language (AML). This research employed qualitative approach. This study followed the steps of data collection and data analysis. The data of this research were obtained through field linguistics method which covered direct elicitation, recording, and elicitation checking. The classified data were clarified with the native speakers of this language to improve the reliability of the data. From the analysis, it can be concluded that morphological causative construction in AML implies that the meaning of cause and effect. It is indicated by the use of suffix -kan and $i$. In addition, causative markers of $-k a n$ and $-i$ in AML can be attached to verbs, adjectives, nouns, and numerals.
\end{abstract}

Keywords: causative, morphological, Asahan Malay Language, suffix

\section{INTRODUCTION}

Causative construction (henceforth CC) can be found in any languages around the world. It is defined as an expression containing an event caused by someone's actions or because something happened (Goddard, 1998). Other expert argue that it is an expression in which an event (the caused event) is depicted as taking place because someone does something or because something happens, that is, if $x$ hadn't happened, y wouldn't have happened (Imoh, 2014). The types of CC that each language has are different from each other. Some languages have all the three types of causative construction (lexical causative, morphological causative and analytic causative) and some languages have only two types ofcausative construction; lexical causative and analytical causative (Zuindra \& Mulyadi, 2020).

In most cases, causativity has the meaning "to cause or to make somebody do something" or to cause something to become something different" (Mutaka, 2000). He specifies that when it is added to intransitive verbs, the causative suffix adds a subject which functions as agent, whereas, 
the inherent subject is displaced and functions as the object. Comrie (1989) states that every causative situation involves two components of a situation or event, cause and effect, it is in line with Shibatani (1976) and Goddard (1998) who argue that causative is a situation occurs on two interconnected events, one showing the cause and the other declaring the effect. Whereas, Dixon (1994) considers that causative is a transitive process, this is quite reasonable that causative markers can convert intransitive to transitive.

Causative construction is divided into three namely lexical, analytical, and morphological causative. Analytical causatives are syntactic constructions with separate verbs such as make. Morphological causatives are created by processes such as affixation. Lexical causatives are words like kill, send, and feed etc (Imoh, 2014; Shibatani, 1976). It is expressed by means of aproductive suffix are referred to as morphological causatives (Hasan, 2011).The example is presented below.

Suratman nggodoke wedang kanggo dayohe. 'Suratman boiled drinking water for hisguest.' (Zuindra \& Mulyadi, 2020)

Lexical causatives refer to morphologically irregular, nonproductive causative forms. They are typically manifested in languages as a class of transitive verbs refer to as causative transitive verbs, such as cut, destroy, open, melt, boil, etc. in English (Hasan, 2011).

The difference in valence of non-causative verbs includes intransitive verbs, transitive verbs, and di-transitive verbs. The relation between causative construction and non -causative construction is explained through the hierarchy of grammatical relations of the subject $>$ direct object $>$ indirect object $>$ oblique object (Junaidi \& Mulyadi, 2019). In the hierarchy of grammatical relations, it is explained that causee occupies the highest position, namely the left position which is the position of the causative argument that has not been filled.

Generally, causativity in several languages in the world occurs on three basic clauses, namely the intransitive basic clause, the monotransitive basic clause, and the transitive basic clause (Comrie, 1989). In each part, the different relation shifting occurs after experiencing acausative process. In this case, relation is the relationship between verbs and arguments that are respectively interdependent in the structure of the clause. The causativity event was described by Comrie (1989) and Purwiati (2012)as follows: 
Table 1. Alteration of Valence of Non-causative Basic Verbs to Causative Verbs (Zuindra \& Mulyadi, 2020)

\begin{tabular}{|c|c|c|}
\hline Type of clause & Non-Causative Basic Verbs & Causative Verb \\
\hline \multirow[t]{2}{*}{ Intransitive } & SUBJ & SUBJ \\
\hline & & OL \\
\hline \multirow[t]{3}{*}{ Monotransitive } & SUBJ & SUBJ \\
\hline & $\mathrm{OL}-$ & OL \\
\hline & & OTL \\
\hline \multirow[t]{4}{*}{ Ditransitive } & SUBJ & SUBJ \\
\hline & $\mathrm{OL}^{-}$ & OL \\
\hline & OTL- & OTL \\
\hline & $\Delta$ & OBL \\
\hline
\end{tabular}

Causative construction describes a micro or event consisting of (1) the event of cause that causes an event and (2) the event that occurs or the result happens caused by the action of cause (Comrie, 1985; Shibatani, 1976).Causer is someone or something that makes someone or something do an action. As suggested by Larson (1984:199) "causer is the thing which instigates the event rather than actually doing it". In the lexical causative there are the term called causer; agent of cause and causee; agent of effect. Other experts define that causer is the agent of the external situation.

Languages that have all the three types of constructions generally belong to agglutinative language type because this type of language has affixes that can be attached to a verb that function to increase or decrease the valence of the verb. Meanwhile, a language that has only two types of causative construction is a type of language known as isolating because the language in general does not have an affix that functions to increase or decrease the valence of the verb.

The research related to causative construction has been done by many researchers around the world. Hasan (2011) attempts to see causative construction in KokBorok language used in Bangladesh. The most remarkable aspect of the causative constructions in Kok-borok is that in double causatives which shows the language KokBorok's unique features if we compare this language with the other South-Asian Tibeto-Burman languages. The findings of mixed causatives show that both periphrastic and morphological devices have been employed in Kok-Borok to convey the meaning of causative constructions. In relation to sub-ethnic languages in Indonesia, Hemmings (2013) illustrates causative construction based on the patterns of -i and -aké 
from a dialect of Javanese, spoken in Malang, East Java. Mayani (2005) explores the use of causative construction in Madurese. She argues that based on morphosyntactic parameter, it has three facets of causative construction namely analytical, morphological, and lexical. Then, she also concludes that in Madurese, morphological causative tends to be direct, on the other hand, analytical causative tends to be indirect. Nazara, Sudipa, Artawa, \& Satyawati (2019) in their research explore causative construction in Nias language. They conclude that some causatives are formed by attaching prefix $\{\mathrm{fe}-\}$ or its allomorph $\{\mathrm{f}-\}$ to an intransitive verb. Some are formed by morpholexical operation involving suffix $\{$-ö $\}$ and an adjective or suffix $\{$-gö $\}$ and a precategorial. Both morpholexical operations involving prefix and those involving suffix and the base introduce direct causers. Some causatives are formed by attaching confix $\{$ fa-...-ö $\}$ to a transitive verb as the base.

Bahasa Melayu Asahan or Asahan Malay Language (AML) is a dialect which is commonly used by speakers in Asahan and Tanjungbalai region. The study related to this language is important due to some facts as stated by Mulyadi (2010). Some of the reasons are the native speakers of this language tend to use Bahasa Indonesia in their daily activities; there is also a pressure from other languages such as Batak Toba language, Minangkabau language, Javanese that causes variation in AML. Those reasons make the study of causative construction in AML become urgent. Considering the previous studies, therefore, this study attempts to see morphological causative in Asahan Malay Language. This research is expected to be beneficial in broadening the horizon of Malay language studies specifically in morphosyntactic area.

\section{METHODS}

This study used qualitative approach. The data in this study were in the form of sentences. This research includes data collection and data analysis. The research begins with the process of capturing data from Asahan Malay Language (AML), collecting, identifying and classifying. The data of this research were obtained through field linguistics method which covers direct elicitation, recording, and elicitation checking. The data that have been classified were analyzed with the appropriate steps. The classified and analyzed data were clarified with the native speakers of this language (Mr. ASW, Mrs. AL, Ms. AA, dan Ms. ANA) whether the utterances are exist and commonly used in AML in order to improve the reliability of the data. Then, the analysis was also checked by the experts in morphosyntactic analysis from department of Linguistics of Universitas Sumatera Utara.

\section{FINDINGS}

\section{Morphological Causative}


Morphological causative formation generally implies combining morphemes forming a morphological unit within which the idea of causation is expressed or implied (Comrie, 1985; Imoh, 2014). The example of morphological causative in AML is presented in the following examples:

Dio masuk-kan adik-nyo ke sakolah jalan Sudirman-tu.

He enroll-CAUS younger brother-POSS PREPt he school at

Sudirman st DEM.

'He enrolled his brother to the school at Sudirman st.'

Ipul bongak-I cewek-nyo semalam tentang pesta itu

NAME lie-CAUS girlfriend-POSS yesterday about party DET

'Ipul lied to his girlfriend about the party'

In example (1) and (2), the suffix -kan is added to the verb 'masuk' 'enroll' and 'bongak' 'lie' in order to form causativity. The base forms are the verb 'masuk' 'enroll', and 'bongak' 'lie' which are not causative, but after the process of affixation, the sentence is regarded as causative.

Derived from noun

Dio parkara -kan tanah itu keuwak-nyo.

He problem-CAUS land that to uncle POSS

'He problematizes that land to his uncle'

Dio-men-duit-kan samuonyo samo kawan-nyo

He Pref-money-CAUS everythingto friend-POSS

'He monetizes everything to his friend'

Uwak-tu me-ludah-i muko bini-nyo

Man-DET Pref-saliva-CAUS face wife-POSS

'That man spits his wife's face on'

Encet mang-gulo-I teh-tu banyakbonar

NAME Pref-sugar-CAUS tea-DEM much so

'Encet sweetens the tea so much'

Sentence (3) (4), (5), and (6) are examples of the causative processes derived from nouns based on morphological parameters. In AML, the base duit 'money', ludah 'saliva', and gulo 'sugar' are not containing causative meaning, but after the process of affixation by adding suffix $-i$, the sentences contain causative constructions.

Derived from numeral

Cewek-nyo man-duo-kan-nyo

Girf-POSS Pref-two-CAUS-POSS

'She cheats on him'

Amat ma-nyatu-kan duo kaluargo di kampong-tu

NAME pref-one-CAUS two family PREP village-DEM 
'Amat unites two families in that village'

Sentence (7), and (8) are examples of the causative processes derived from numeral duo 'two' and tigo 'three' based on morphological parameters. After being add by affixation $-i$ the construction becomes causative.

\section{Derived from adjective}

Minah mam-bodoh-I Joma.

NAME pref-stupid-CAUS NAME

'Minah tricks Joma'

Angkot ma-nyusah-kan hidupomak-nyo.

NAME Pref-difficult-CAUS life mother-POSS

'Angkot troubles his mother's life'

Sentence (9), and (10) are examples of the causative processes derived from adjectives bodoh 'stupid' and susah 'susah' based on morphological parameters. It has derivational process. The word 'bodoh' becomes causative after being given by affixation $-i$ to form causative construction.

\section{DISCUSSION}

Every language owns a different grammatical construction from one another in expressing causative construction (Junaidi \& Mulyadi, 2019). A morphological causative as one of types of causatives means the predicate (which hitherto was non-causative) undergoes some derivational process in order to express causativity, there being no separately expressed predicate of causation (Comrie, 1985; Cổn, 2020). This type is signed by the use of morphological marker.

Azizah, Artawa, Indrawati, \& Satyawati (2020) state that a causative structure happens when its predicate is filled with verbs that are formed from morphological processes in such a way to produce causative verbs that have morphological characteristics. The causing event and the caused event are encoded in a single verbal complex via causative morphology (Anyanwu, 2012). In addition, the causing event and the caused events (effect) are two main components of events (Cổn, 2020; Sudtedi, 2020) that is semantically biclausal, but semantically monoclausal (Baratashvili, 2019).

In the example (1) and (2), it can be seen that there is suffix -kan attached to the predicate masuk (Enroll). Suffix -kan is the sign of morphological causative (Afriani, 2016; Hadi, 2008). In sentence (1), causative -kan was attached to di-transitive verb 'masuk' 'enroll' so that the causing event is clearly expressed by regular morphological process. It is also relevant to the statement by Baratashvili (2019) that the process of affixation as a result of morphological process affects the process of causativity which is then called as morphological causative. In Standard Indonesian, the critical role of the the 
suffix -kan is to convert an intransitive or (rarely) a monotransitive verb to a causative verb even though it seems to possesses some other functions such as benefactive applicative (Yanti, McKinnon, Cole, \& Hermon, 2021).

In example (2), causative marker $-k a n$ was attached to noun. It is also in line with other studies done by Azizah et al. (2020) that this process possibly include internal changes such as consonant repetition, reduplication, vocal extension and the like, or various affixations. In AML, besides suffix $-k a n$, suffif $-i$ is one of other marker of affixation to form morphological causative.

The suffix $-i$ is the marker of causative. In sentence (3), the subject Ipul is the agent and there is the addition of argument structure with increasing valency level of the intransitive verb 'lie'. The effect of adding causative affixes $-i$ was the addition of arguments that function as cause. In example (1), there is also an increasing valency level of intransitive verb.

The causative markers of-kan and $-i$ in AML can be attached to verbs, adjectives, nouns, and numerals in order to form causative verbs. In other languages such as in Madurese, causative verb is commonly marked by prefix $m a$ - in the form of adjective (Salsabila \& Subiyanto, 2020).

\section{CONCLUSION AND SUGGESTION}

From the analysis, it can be concluded that morphological causative construction in AML implies that the meaning of cause and effect. It is indicated by the use of suffix $-k a n$ and $-i$. In addition, causative markers of$k a n$ and $-i$ in AML can be attached to verbs, adjectives, nouns, and numerals. Since this study is limited to the analysis of morphological causative construction, further researchers are suggested to explore analytical and peripheral causative. In addition, further researcher can also conduct further studies related to AML such as passive construction, relative clause construction, etc.

\section{ACKNOWLEDGEMENTS}

The writers would like to direct their appreciativeness to Mr. ASW, Mrs. AL, Ms. AA, dan Ms. ANA for their help in accomplishing this article.

\section{REFERENCES}

Afriani, S. H. (2016). Kausatif dalam bahasa Indonesia dan bahasa Inggris: Sebuah telaah tipologis. Tamaddun: Jurnal Kebudayaan dan Sastra Islam, 16(1), 81-94.

Anyanwu, O. N. (2012). Ibibio Causative and Anti-Causative Verb Alternations. English Linguistics Research, 1(2), 106-114. https:// doi.org/10.5430/elr.v1n2p25

Azizah, N., Artawa, K., Indrawati, N. L. K. M., \& Satyawati, M. S. (2020). Causative in Sasak: A Mechanism of Valency Increase. Journal of 
Language Teaching and Research, 11(3), 491-496. https:// doi.org/10.17507/jltr.1103.19

Baratashvili, Z. (2019). The types of the causative construction in Georgian. Bullletin of the Georgian National Academy of Sciences, 13(1), 126-136.

Comrie, B. (1985). Causative verb formation and other verb deriving morpholog (T. Shopen, Ed.). Cambridge: Cambridge University Press.

Comrie, B. (1989). Language universal and linguistc typology. Oxford: Blackwell.

Cổn, N. H. (2020). Causative Constructions in Vietnamese: From a typological Perspective. International Journal of Language $\mathcal{E}$ Linguistics, 7(2), 51-57. https://doi.org/10.30845/ijll.v7n2p6

Dixon, R. M. W. (1994). Ergativity. Cambridge: Cambridge University Press.

Goddard, C. (1998). Semantic analysis: A Practical Introduction. Oxford: Oxford University Press.

Hadi, W. (2008). Konstruksi kausatif bahasa Serawai. Bahas, 35(69), 1-10. https:// doi.org/10.24114/bhs.v0i69TH\%20XXXV.2373

Hasan, M. K. (2011). Causative constructions in Kok-Borok. Dhaka University Journal of Linguistics, 2(4), 115-137. https:// doi.org/10.3329/dujl.v2i4.6902

Hemmings, C. (2013). Causatives and Applicatives: The case for Polysemy in Javanese. SOAS Working Papers in Linguistics, 6, 167-194.

Imoh, P. M. (2014). Causative Constructions: A Descriptive Analysis. UJAH: Unizik Journal of Arts and Humanities, 14(2), 66-89. https:// doi.org/10.4314/ujah.v14i2.4

Junaidi, \& Mulyadi. (2019). Causative construction of Peu- and Seu- in Acehnese language. European Journal of Applied Linguistics Studies, 2(1), 15-30. https:// doi.org/10.5281/ZENODO.3352266

Mayani, L. A. (2005). Konstruksi kausatif bahasa Madura. Linguistik Indonesia, 23(2), 237-249.

Mutaka, N. (2000). An introduction to African linguistics. Berlin: Lincoln Europa.

Nazara, W., Sudipa, I. N., Artawa, K., \& Satyawati, M. S. (2019). Causative constructions in the language of nias. International Journal of Social Sciences and Humanities, 3(2), 208-216. https:// doi.org/10.29332/ijssh.v3n2.316

Purwiati, I. A. M. (2012). Sistem konstruksi kausatif bahasa Bali. Widyaparwa, $40(1), 69-78$.

Salsabila, F. N., \& Subiyanto, A. (2020). Benefactive verbs and causative verbs in Madurese: Morphosyntactic analysis. Linguistic, English Education and Art (LEEA) Journal, 4(1), 88-98. https:/ / doi.org/10.31539/leea.v4i1.1826

Shibatani, M. (1976). The grammar of causative constructions (M. Shibatani, Ed.). New York: Academic Press. 
Sudtedi, D. (2020). Japanese and Indonesian causative contrastive analysis. International Journal of Arts, 1(6), International Journal of Arts, Humanities\&Social Science.

Yanti, McKinnon, T., Cole, P., \& Hermon, G. (2021). The typology of applicative/causative marking in Tapus. Linguistik Indonesia, 39(1), 128. https:// doi.org/10.26499/li.v39i1.188

Zuindra, \& Mulyadi. (2020). Morphological and analytical causative construction in Deli Javanese dialect. Language Literacy: Journal of Linguistics, Literature and Language Teaching, 4(1), 121-132. 